\title{
12
}

\section{SPATIAL TRANSFORMATIONS AND SPATIO-TEMPORAL COUPLING}

\section{Links between everyday shopping behavior and changes in the retail landscape}

\section{Elmar Kulke and Nina Baur}

\section{Interrelations of time and space: spatio-temporal pathways}

Löw and Knoblauch (in this book) claim that since the 1970s, spaces have been refigured at a rather fast pace and within a relatively short period of time. Similarly, in accordance with most economic theories, spatial transformations should occur rather frequently and quickly-whenever production costs or consumer demands change, for example, companies should restructure their locations of production and retailing along with their value chains. However, at least for the economy, the contrary is true from an empirical standpoint. For example, Boatcă, Bhambra, Korzeniewicz, and Payne (all in this book) illustrate at the level of the world system that spatial transformations occur much more seldomly than both economic theories and the concept of refiguration of spaces suggest. Indeed, if they occur, spatial transformations unfold much more slowly, usually in the longue durée (Braudel 1958), and path-dependently. This is important not only as an aspect in the spatial structure of the economy but also because of the fact that the economy is a key factor in (re-)producing social inequality. Similar effects can be observed at the national and regional levels, where regional disparities of both the economic structure and social inequality have been continuously reproducing over an extended period of time (Storper in this issue; Heidenreich 2003).

Various explanations have been provided as to why the spatial structures of the economy are so slow to transform, including: power structures within the world system (Wallerstein 2004); constructions of race, nationality, and citizenship as aftermaths of colonialism (Boatcă, Bhambra, both in this book); spatial strategies of transnational elites (Korzeniewicz and Payne in this book); the agglomeration of infrastructure and institutions in regional innovation systems (Hassink, Ibert, and Sarnow 2020; Heidenreich and Baur 2015; Storper in this book); the material 
structure of global value chains (Beyer et al. in this book); and local economic conventions, values, and culture (Baur et al. 2014c, Storper in this book).

In this chapter, we provide an additional explanation for the sluggishness of spatial transformations, complementing these earlier accounts: the spatial and temporal coupling of institutions. The idea of "coupling" is based on the observation that space and time are inextricably entwined in both the economy and everyday life, as geography (e.g. Massey 2005) and sociology (e.g. Löw 2001; Baur 2005, 80-82, 165-172; Weidenhaus 2015) have repeatedly stressed. In this context, it is necessary to distinguish between people's spatio-temporal knowledge ("Soziale Raumzeit," "Raum- und Zeitwissen")—how people experience and interpret their living spaces ("Lebensraum") and their life histories ("Lebensgeschichtlichkeit") in their individual biographies (Weidenhaus 2015) — and their actions. With regard to people's actions in space and time, it is important to note that at any given point in time, the materiality of the surroundings determines people's actions and interactions, as each person and object (i.e. good) can only be at one location (i.e. at a specific space-time coordinate) at a given time. In modern economies, goods are typically transported over long distances and people commute between their homes and work spaces. Moving people and goods through (physical) space from one space-time coordinate to another takes time (Baur et al. 2014a), which is why specific spatio-temporal pathways ("Raum-Zeit-Pfade") can be observed (Cromley 1999, 64-82, 104-116).

In order to save time and facilitate coordination across time and space, different activities are often "coupled"- that is: combined - at the same locations. This has been demonstrated both in geography and sociology for consumers' everyday lives and in geography for economic activities. Using the example of consumer-retailer interactions when shopping for groceries in West German cities, we take this one step further in this chapter: We will not only show (a) how consumers (demand side) couple shopping with other everyday activities and (b) how retailers (supply side) couple their outlets with other retailers and social institutions but also (c) how demand and supply side are coupled and (d) how this coupling is embedded in the material urban structure, (e) which in turn is at the root of the slowness in spatial transformations.

\section{Consumers: the driving forces behind coupling on the demand side}

When analyzing consumer-retailer interactions on the demand side, one can observe that in theory, consumers today should both go shopping more often and spend more time on shopping than was the case 70 years ago due to increasing incomes, new lifestyles, and a new household division of labor.

First, people's ability to afford products has dramatically increased. Up to the $1950 \mathrm{~s}$ in Germany, markets were characterized by insufficient supply, and a lack of food was an everyday experience. Since then, however, grocery stores have been saturated and driven by excess supply. In parallel, real household incomes have increased 
continuously (Ermann and Pütz 2020). As a result, in 2019, the average income was 33 times higher than 70 years ago (Destatis 2020, Figure 12.1).

Increased income encourages changes in consumption behavior, which is described by the classic Engel curves (Engel 1857; Kulke 2017): Low-income consumers can only afford to buy a limited number of goods and have to spend most of their available money on basic necessities (such as food), which therefore are not income elastic. When incomes increase, consumers both buy more goods and spend a larger share of their income on income-elastic, high-quality, or expendable goods (e.g., durable consumer goods, entertainment, electronics). Consumers typically do not buy more necessities but rather buy similar goods of a higher quality, for instance, by switching from cheap no-name articles to brand products. Regardless, in 2013, German couples with children still spent about $15 \%$ of their household income on food (Destatis 2016, 158). Higher income also equates to an increase in individual mobility, as households increasingly own private means of transportation, especially cars (Achen et al. 2008). Cars allow consumers to travel faster and to shop at more distant and varied retail agglomerations. All in all, income

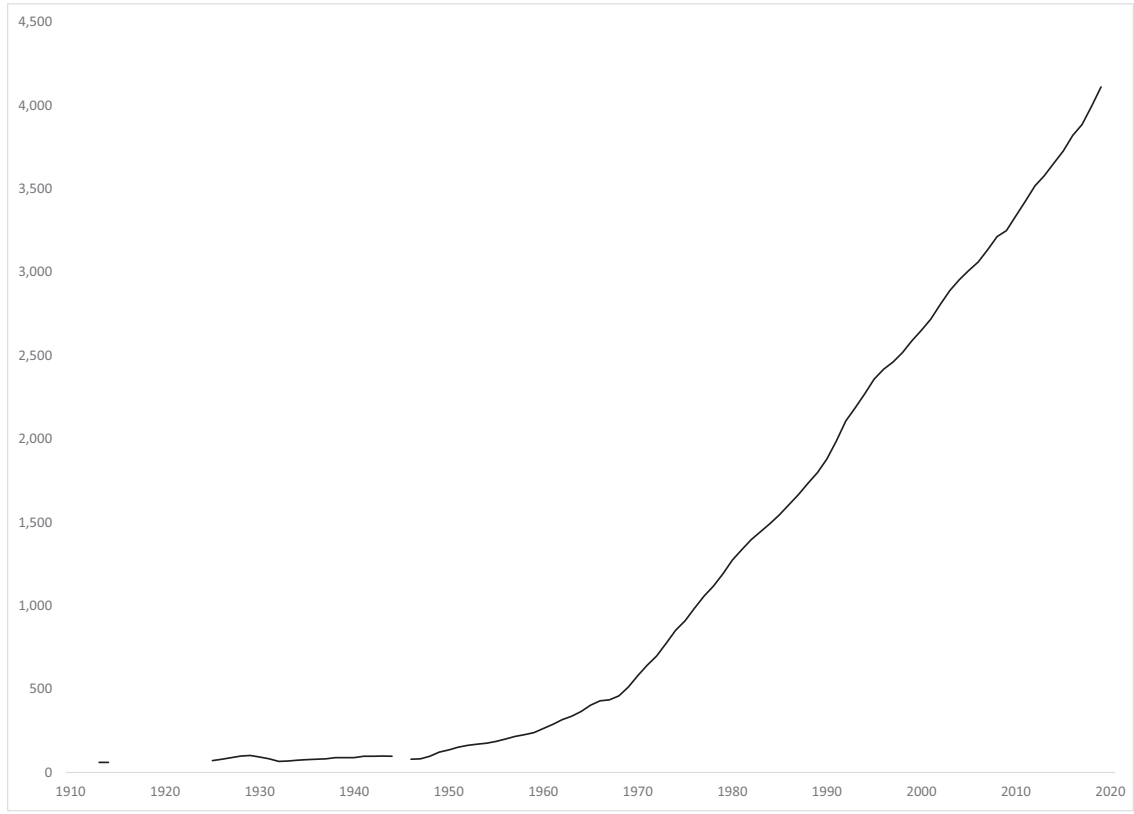

FIGURE 12.1 Average monthly gross income of German full-time employees 19131919 (in Euro)

Source: Own calculation based on Destatis 2020. The working population consists of the employees in production and services of the respective territory at the time, namely the German Reich 1913-1944, the American-British Bizone 1945-1949, the territory of the former Federal Republic of Germany since 1949 (without Saarland and Berlin 1950-1959, without Berlin 1960-1963, including West Berlin 1964-2006, including Berlin since 2007). 
increases should impact spatio-temporal pathways, as buying more goods-at least in theory-requires more time dedicated to shopping and going to more shops.

Second, shopping behavior is only one of many daily activities needed to maintain a family. Modern urban West German families-for example, consisting of two adult partners with small children living in a single household - typically perform unpaid work (housework and care work) in addition to enjoying some leisure activities (e.g., watching TV, playing, receiving visitors) at home. If the household's adults perform their paid work outside their homes, they need to commute to/ from their office. They also have to ensure that their children are transported to/ from their (nursery) schools. Additional journeys result from diverse leisure activities (e.g., sports, day trips, meeting friends, eating out, visiting concerts) as well as housework and care work (e.g., shopping, seeing a doctor). In other words, the daily routines of a family's members are linked.

As people's overall time budget is limited, in order to save time, there typically is a household division of labor between the adult family members, which can take on different forms. From the nineteenth century to the 1950s, the "male breadwinner/female homemaker model," in which the man concentrates on work and the woman takes care of housework and carework, was common practice. Since the 1960s, due to changes in both the welfare state and social norms, the "dual career model," in which partners share these tasks evenly, has increasingly become more common (Baur 2007). This is reflected in female labor market participation: In many countries (including Germany), only $40 \%$ of women were employed in the 1960s and 1970s, while 55\% were employed in 2016 (Grunow 2019, 258). Although gender ideologies have expanded since the 1950s (Baur et al. 2019; Grunow 2019), there is surprisingly little change in the general structure of the household division of labor (Grunow 2019, 260, 276): In 2012/13, men spent about $57 \%$ of their total work hours on paid work and $43 \%$ on unpaid work-for women, it was the opposite with a ratio of $35 \%$ to $65 \%$, meaning that, on average, men spent nine hours more per week on paid and ten hours less per week on unpaid work than women, and the gender gap in overall work time has even increased still further since the early 2000s (Destatis 2016, 263).

What is rarely taken into account in debates on the household division of labor is its implications for spatio-temporal pathways: Different activities - such as cleaning and cooking, shopping, paid work, dropping off the children at school, visiting doctors, banks and public administrations - take place at different places scattered around the city: the home, shops, the office, childcare facilities, schools, government offices, etc. Consumers do not have a choice in the matter because, during the period of industrialization, the division of spheres was materially engrained in the urban structure- referred to as objectified form-investions (Hering and Baur 2019). Consumers are therefore forced to spend time commuting between these places.

As a result, more than half of housework is dedicated to commuting, shopping, and cooking: Of the 29.5 hours per week women dedicated to housework in 2012/13, they spent 2.7 hours per week commuting, 6.1 hours per week shopping and putting away the goods they had bought, and 6.9 hours in the kitchen, while 
men spent 5.7 hours per week less on these tasks. Namely, men spent 2.1 hours per week commuting, 4.9 hours per week shopping, and 3 hours per week cooking (Destatis 2016, 263). Depending on the database, in the 2010s, Germans went shopping between 3.5 times (Papastefanou and Zajchowski 2016, 120) and 4.5 times (Procher and Vance 2013, 8) per week. When Germans left their homes, two out of three trips involved some form of shopping (Destatis 2016, 343). The working population commutes much more often and over longer distances: On a given working day, nine out of ten Germans leave their homes and make an average of four journeys, mostly by car. In doing so, commuters cover about 10 to 12 kilometers per journey, requiring between 84 and 90 minutes in total (Destatis 2016, 341-342).

Due to the above-mentioned changes in the household division of labor, commuting times at least should have increased since the 1960s: In the male breadwinner/female homemaker model, commuting time is minimized as men travel to work places that are typically located in a different neighborhood or even city than the home, while women perform all tasks that can be completed in the home neighborhood, including shopping (Figure 12.2a). In contrast, in the dual career model, both partners have to travel to all places because they share all tasks, thus multiplying overall commuting time (Figure 12.2b).

Consequently, all in all, both commuting time and time spent shopping should have increased since the 1960s, due to both increasing incomes and changes in the household division of labor. However, paradoxically, since the 1980s-when mobility patterns were first systematically measured in Germany-both the percentage of commuting persons and the average time spent commuting have not increased but rather have stayed more or less constant (Destatis 2016, 341-342). Similarly, both men and women only spent about half an hour more shopping in the 2010s than in the early 2000s (Destatis 2016, 263).

The reason for this is that couples' overall time budget remains the same-if new tasks are added, couples have to reduce the time spent on other tasks (Hofmeister and Moen 2012). To a certain extent, working hours have been decreasing since the 1960s (Grunow 2019). However, as working hours are partly regulated nationally and partly negotiated by labor unions, couples have a limited influence on their total working hours if both want to work. Instead, couples have been saving the most time by spending less time on housework since the 1950s (Baur et al. 2019). Women's average time spent on routine housework decreased from more than four hours per day in 1965 to less than three hours in the 2000s. At the same time, men's average time spent on routine housework has only increased from 17 minutes in 1965 to 49 minutes in 2001 (Grunow 2019, 258). As a result, the total working hours - for paid work, housework, care work, shopping, and commuting-have been steadily decreasing since the 1950s and decreased further by about 45 minutes between 2001/2002 and 2012/2013 (Destatis 2016, 263).

This reduction in housework was partly driven by technological change (Baur et al. 2019). However, and more importantly, consumers have reacted to time pressure by coupling activities in their daily life. In the 2010s, when going shopping, only one 
(a) Male breadwinner and female homemaker family, 19th century to $1950 \mathrm{~s}$

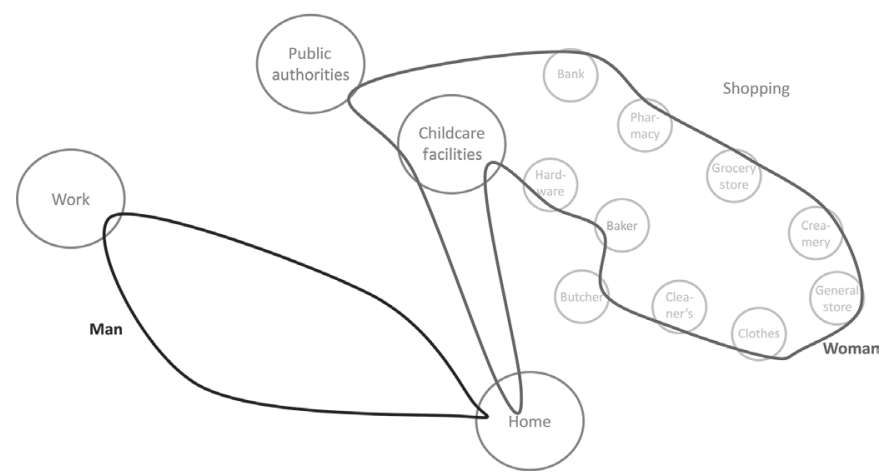

(b) Dual-earner family, 19th century to $1950 \mathrm{~s}$

Inner cities Suburbs

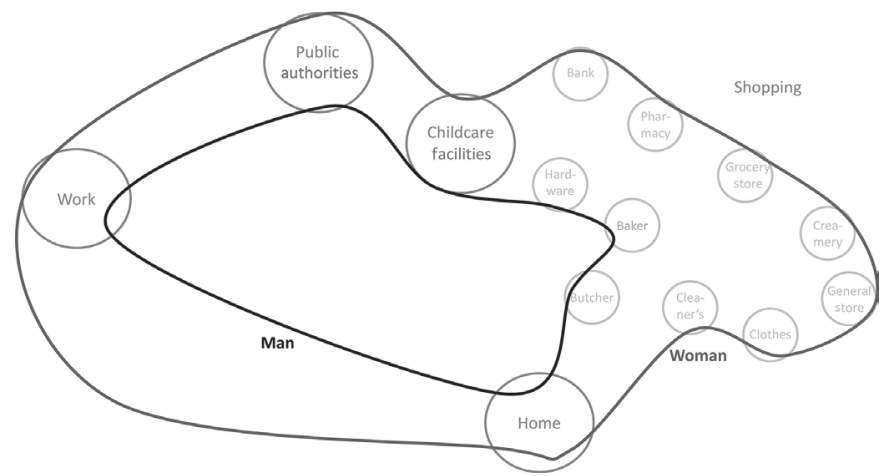

(c) Dual-earner family, 1960 s to 1970

Inner cities Suburbs

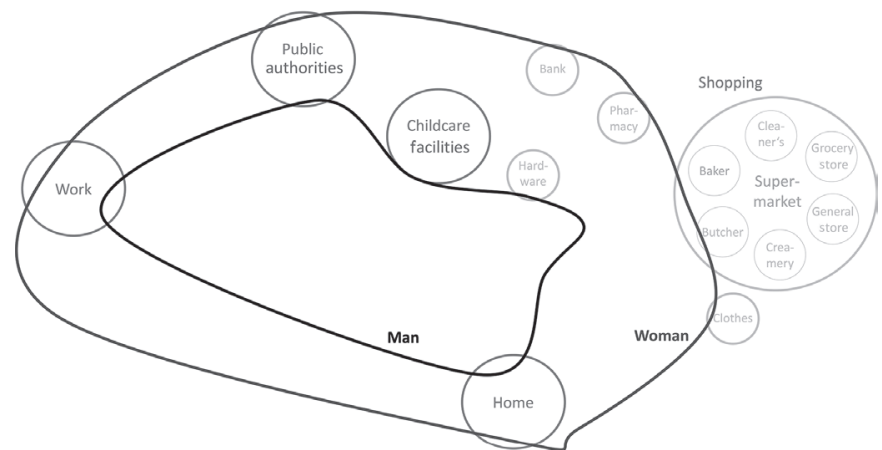

FIGURE 12.2 Typical spatio-temporal paths of couples with children on workdays depending on household division of labor and retailing structures 
(d) Dual-earner family, since 1980s

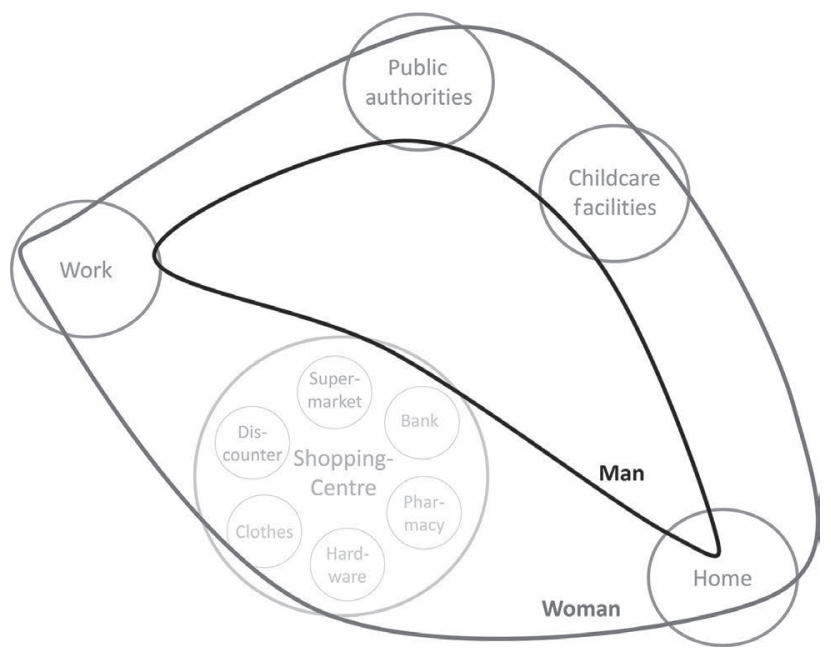

FIGURE 12.2 (Continued)

in three trips was solely dedicated to shopping, while two out of three trips coupled shopping with other activities (Destatis 2016, 343). In addition, consumers also couple different types of shopping activities.

In connection with rising income and mobility, motives for shopping have become increasingly differentiated (Kulke 2005; Weiss 2006). Entertainment shopping (coupling shopping with leisure activities such as visiting a restaurant), discount shopping (buying in stores with an assortment of articles at low prices), and smart shopping (buying well-known brand products for low prices) are gaining in importance. In the course of this differentiation, the connections within closest proximity-the so-called nearest-center-connections-have dissolved and more distant shopping locations are visited more often (Martin 2006).

\section{Temporal coupling of retailing with other social institutions}

It is important to note that individual people do not have much choice about how to organize their everyday lives, because when people (e.g., the members of a family) interact, their actions need to be spatially and temporally synchronized (Maurer 1992; Baur 2005). Therefore, people's spatio-temporal knowledge and spatio-temporal pathways (micro level) are embedded in spatio-temporal regimes (macro level), which are both material (objectified) and social. Although temporal and spatial regimes are obviously linked, so far, sociology has mostly focused on time regimes ("Zeitordnungen") and geography on material spatial orders ("Raumstruktur"). 
As sociology has shown, any social group — such as a family or a companyis synchronized by means of a time regime ("Zeitordnung") (Buchmann 1989; Fürstenberg 1986): Based on collective temporal knowledge ("Zeitbewusstsein") (Bergmann 1983), the social group defines a set of temporal rules that structure people's schedules in a typical and binding way, so that anyone can rely on the others' schedules. In Germany, for instance, the traditional working hours (“Kernarbeitszeiten") are 9:00 a.m. to 5:00 p.m. (Monday to Friday). Time regimes are embedded in and at the same time enforced by institutions (e.g., companies, kindergartens, schools). If different institutions do not coordinate their individual time regimes ("Eigenzeit") (Luckmann 1986), this might result in time conflicts ("Zeitkonflikte") at the individual level (Fürstenberg 1982). For example, if the employer expects an employee to be at the office from 9:00 a.m. to 5:00 p.m. but kindergartens and schools are open only between 8:00 a.m. and 1:00 p.m., this means that the same person cannot be employed and take care of the children at the same time. At the household level, this means that either only one partner can be employed or the couple cannot have children (Baur 2008).

Time conflicts are partially resolved by an implicit hierarchy that defines which institution's time regimes take precedence in cases of time clashes. In Germany, work usually takes priority over childcare which in turn takes priority over shopping, meaning that people can only go shopping when they are not working or doing carework. This institutional hierarchy means that retailers are largely forced to react to time conflicts created in other fields of social life.

An initial conflict to which retailers needed to react was the fact that shops require employees to operate and $72 \%$ of salespersons are women (BA 2020). This created a time conflict even in the 1950 s, and retailing has responded to this by means of lobbying. As a result, German legislation defined a compromise in 1956 that stores may only open from Monday to Friday between 7:00 a.m. and 6:30 p.m. and on Saturdays until 2:00 p.m. (Papastefanou and Zajchowski 2016, 117), which allowed most workers to shop before or after work and salespersons to shop and do their housework at a different time. As this did not suffice to resolve the time conflicts, the strict regulations of opening hours have been relaxed since 1989. Since 2006, stores may open 24/6 (Monday to Saturday). This in turn had consequences for people's spatio-temporal pathways in their daily routines, as the average time people spend in stores has increased (Papastefanou and Zajchowski 2016).

A second time conflict arose as a result of changing consumer demands. As discussed previously, these have mainly been determined by three different factors (Lange 1973; Kulke 2017): first, the time available for shopping (shopping time); second, the time needed to reach the shopping locations (commuting time); and third, the transport capacity for articles. Available shopping time and commuting time (which in turn depend on the specific household division of labor) define the minimum coupling of activities needed to obtain all required articles. Transport 
capacity defines the maximum coupling that is possible - cars offer larger transport capacities (compared to walking or using a bike). Changing household divisions of labor and increases in income (with more articles bought) enhance the need for consumers to couple activities.

Since the 1950s, retailers have been reacting to changing consumer needs using a series of organizational innovations consisting of two elements: internal parameters of action mainly address time conflicts and change the store's characteristics; external parameters address locational choices and increasingly couple stores closer together in terms of space.

Internal parameters of action are documented in the rising importance of larger retail formats. These larger formats have developed because they allow consumers to buy different products at once, while at the same time enabling retailers to achieve internal economies of scale, offer more and more diverse articles, and implement different business strategies. According to the life-cycle model of retail formats (Dannenberg, Franz, and Leper 2016; Kulke 2017; Neiberger and Steinke 2020), every retail format is only competitive for a limited time span. Changing consumer preferences and changing internal cost/revenue structures drive the development of new formats, which replace older formats that no longer suit the market conditions. A retail format's life-cycle begins in the phase of market entry with only a few stores and a limited market volume of sales. If a store concept proves successful, it enters the expansion phase, during which many additional units of this format are established and the market share increases rapidly. After some time, the maturity phase is reached. The market share remains more or less constant and no additional units are opened. Finally, the format reaches the phase of decline, during which the units of this type are replaced by new formats and the market share declines.

There is strong empirical evidence for the life-cycle model. For example, in food retailing, until the 1950s, small service stores dominated the market (Figure $12.2 \mathrm{a} / \mathrm{b}$ and Figure 12.3a), which were replaced by store concepts that allowed consumers to minimize their time spent shopping by combining activities, namely buying different goods in the same store and decreasing the time needed for paying and commuting: self-service stores in the 1960s and 1970s (Figure 12.2c) and later larger supermarkets (more than $400 \mathrm{~m}^{2}$ of retail space). Since the $1990 \mathrm{~s}$, supermarkets have been under pressure due to the rise in discounters- which are more or less the same size as supermarkets but offer a smaller range of goods for lower prices - and hypermarkets - which are larger (more than 1,500 $\mathrm{m}^{2}$ of retail space) and offer a wider range of products, including non-food items (such as household goods and clothing). Comparable developments can be seen in non-food retailing. The classic specialized stores have been gradually replaced by larger, self-servicebased, specialized markets and discount stores.

In addition to offering a wider and deeper assortment, these larger stores position themselves on the market by employing special internal action parameters. To boost their competitiveness and to attract consumers, they use either the "price 
(a) Closed traditional food store

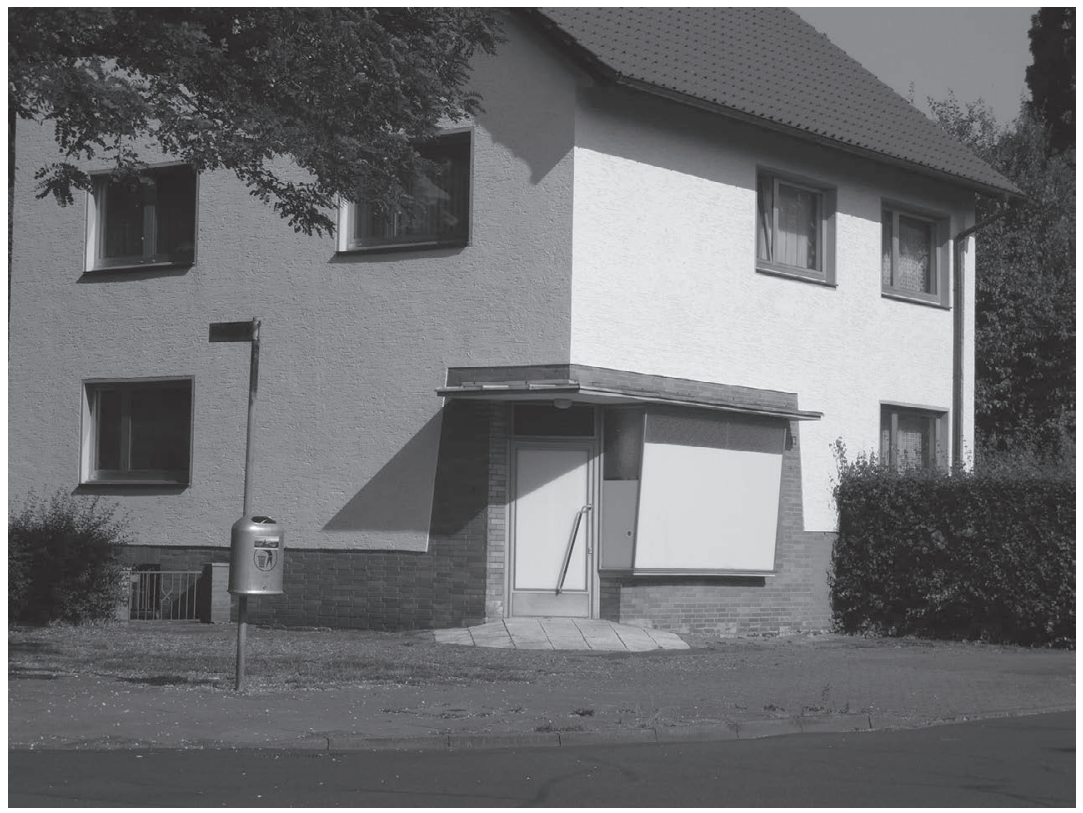

(b) Modern inner-city shopping center

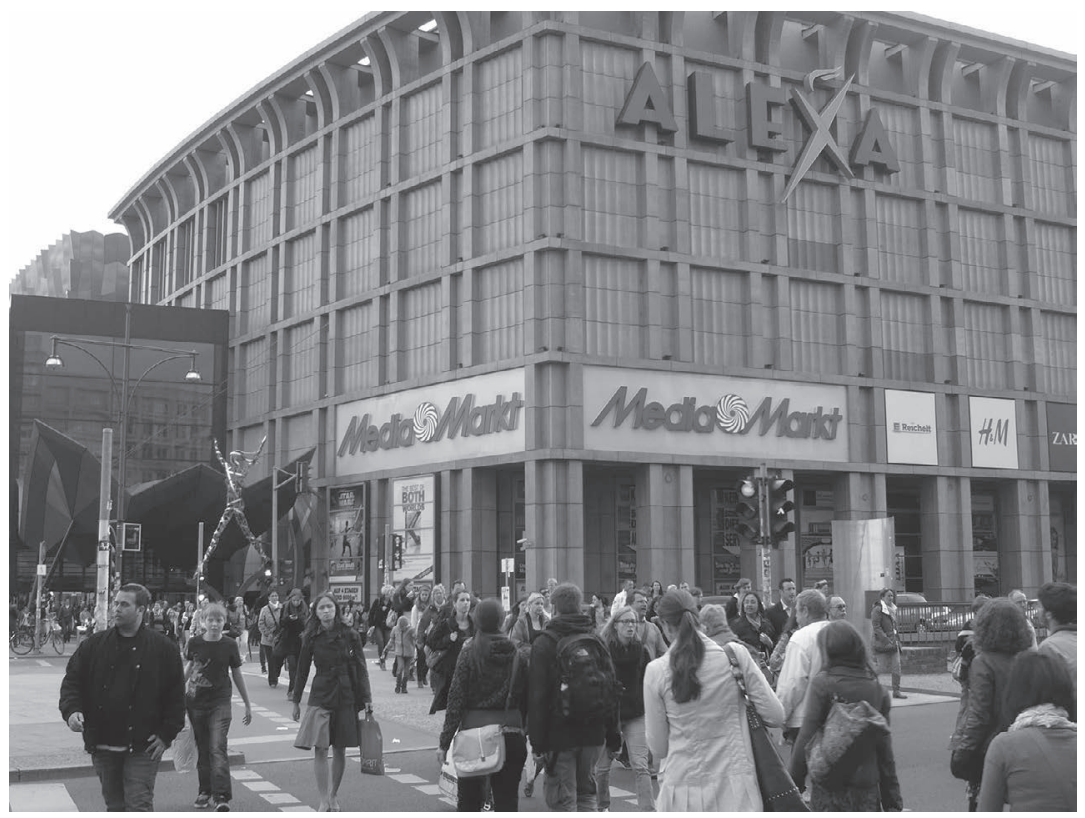

FIGURE 12.3 Different types of retail structures and urban structures

Source: Photos by Elmar Kulke 
Price parameter:

Assortment parameter:

Service parameter:

Distance parameter: increase attractiveness by offering articles at low prices and internal cost reductions

increase attractiveness by optimizing/broadening the assortment of articles offered

increase attractiveness by providing additional services increase attractiveness by optimizing spatial accessibility for consumers

FIGURE 12.4 Action parameters used by retail stores

Source: Agergard, Olsen, and Allpass (1970), Kulke (2017)

parameter," the "assortment parameter," the "service parameter," or the "distance parameter” (Figure 12.4).

\section{Spatial coupling of retailing and changes in the retail landscape}

Changes in both retailing formats and action parameters result in locational changes for retailers because each format and action parameter implies specific locational preferences - and this points to the fact that institutions are coupled together not only temporally but also spatially. As there are different ways of organizing space and time collectively and socially (Baur et al. 2014b, 2014c), each city has its own rhythm (Rinderspacher 1988; Promberger et al. 1997). Over time, time regimes are engrained in a city's objectified spatial structure ("Raumstruktur") by constructing buildings and transport infrastructure that facilitate actions in compliance with the city's time regime and at the same time make deviant actions more difficult (Simmel 1901, 254-270; Elias [1969] 2002). In other words, both a city's rhythm and its physical spatial structure assume a specific household division of labor, and the city's spatio-temporal order is structured based on that assumption (Hering and Baur 2019). For example, since the industrialization of the nineteenth century, West German spatio-temporal regimes were organized according to the male breadwinner/female homemaker model (Baur 2008). Working time was separated from other activities, and the workspace ("Arbeitsort") was physically separated from the home ("Wohnort") (Maurer 1992).

As a result, cities were designed in such a way that the (male) workforce needed to commute to work in different quarters of the city (Hofmeister 2002). As explained earlier, women therefore performed all other tasks, included shopping, and there was an elective affinity ("Wahlverwandtschaft") towards coupling commuting distances and motives for shopping. In the 1950s, (female) consumers typically practiced convenience-oriented shopping, that is, women visited the shop closest to their home offering the goods needed ("nearest-center-connection") (Martin 2006). Within their neighborhood, they had to visit one shop per good-a 
butcher, a baker, a milk/cheese shop, a classic grocery store, etc.- - which were scattered across locations close to their homes (Figures 12.2a and 3a). This resulted in a great deal of commuting time both from work to the shops and between shops, in addition to extra time spent in the shops to pay several times, for example.

As stated previously, since the 1970s, German family ideals have pluralized, and more and more people have wanted to practice a dual-career model (Baur 2008; Baur et al. 2019; Grunow 2019). In theory, this should have increased commuting time (Figure 12.2b). However, this was not the case, as retailers reacted to these changes in consumer demand by changing their external parameters.

External parameters are mainly connected to locational decisions and depend on the store's size, assortment, and strategic action. According to Nelson (1958), every retail store is able to attract a given number of consumers on its own, which is called "generative business." Large units with a diversified assortment - such as hypermarkets or large home depots - attract so many consumers on their own that they can choose locations without taking into account their proximity to other stores. However, for smaller units, their generative business is limited. Therefore, they tend to choose locations close to other stores. This proximity allows all shops to attract more customers, which is referred to as "shared business." This in turn fits consumers' need to relieve time pressure by coupling activities (Kulke 2017). More specifically, since the 1960s, retailers have reacted to the changes in consumer needs by coupling different retail formats such as supermarkets, discounters, and other stores with services, leisure, and infrastructure at a single location (Figure 12.3b): Shopping centers usually consist of several magnet stores and several smaller units, while offering many additional services (e.g., restaurants, bars, hairdressers, banks, cinemas) (Kulke and Rauh 2014). Another example is that supermarkets (such as Edeka or Rewe) and discounters (like Aldi and Lidl) are more and more often co-locating close to each other (Jürgens 2013). Consumers can save time by buying a larger number and wide range of goods with various qualities in one visit (Figure 12.2c).

In addition, external factors generating flows of people can draw additional consumers to a store. Such "higher frequencies of flows" occur at train stations, airports, or highway crossings. When stores are located at these nodes, they can profit from the flow of people, which is called "suscipient business" (Nelson 1958). For consumers, this means that-if shops are located on their way to work-they can also couple shopping with other activities and reduce commuting times. Accordingly, since the 1980s, progressively more stores have relocated to areas in proximity to other stores and close to transport nodes, resulting in a spatial concentration in the retail landscape (Figures 12.2d and 12.3b). Finally, large train stations and airports are developing structures similar to shopping centers (Jenne 2017; Korn 2006).

\section{Objectifying spatio-temporal coupling in the urban structure}

As can be seen from the previous discussion, various spheres of social life, such as family, work, and shopping, have to be coordinated and therefore are coupled together in space and time, giving a city a specific rhythm. As retailing is lowest in 
the institutional hierarchy, it can merely react and adapt to dominant spatio-temporal regimes and resulting consumer demands. However, in doing so, retailing may actually drive social and spatial transformations. For example, by introducing new retail formats, retailers both reacted to changing consumer demands and facilitated families practicing dual-career models. At the level of everyday life, spatio-temporal coupling reveals a paradox, namely: While people should theoretically spend more time on shopping and commuting, they are in fact doing the contrary.

By means of urban and transport design, these spatio-temporal regimes are objectified in the urban structure. This coupling in turn slows down the pace of social and spatial transformations. In fact, the case of Berlin shows that the spatio-temporal regime in place in an urban quarter's formative phase (Berking and Schwenk 2011) has an effect on the retail structure up to the present day (Fülling and Hering 2020), thus slowing down the refiguration of spaces and economic restructuring. This also explains why e-commerce does not have the strong spatial impact it should have in theory, because it offers consumers flexible hours and high coupling potential to shop: Since 2000, online shopping has offered consumers easy possibilities to see products, compare prices, and purchase merchandise from home or work (Dederichs and Dannenberg 2017; Kulke 2019). However, even in 2019, e-commerce's market share of the total retail turnover in Germany was still only 11\% (HDE Online-Monitor 2019). The reason for this is partially that perishable groceries vary so much in terms of their quality that consumers want to see them in real life before they buy them. However, and more importantly, while consumers can order online, not everything can be delivered everywhere. Rather, consumers can only order goods online from the retailers in their quarter (Hering 2020).

Finally, in the long run, spatio-temporal coupling does have an effect, resulting in market and spatial concentration. A new household division of labor, income increases, limited time for shopping, better mobility, and new shopping motives have encouraged a change in the spatial distribution of demand (Kulke 2020). Small stores in scattered locations and smaller centers are facing a severe reduction in turnover and often have had to close. Larger stores with a diversified assortment of articles and shopping agglomerations with several stores have generated an over-proportional increase in turnover. In most cases, they are located in central areas of the urban agglomerations or at de-central locations with good road connections.

For future research, this means that different spheres of social life are interlocked, with the city as the unit of analysis. As there are different ways in which these spheres are interlocked, future research should compare different cities with as contrasting household divisions of labor and economies as possible. In addition, this type of research should take into account the longue durée, as many of the more important spatial transformations are taking place much more slowly than predicted by most economic theories and the concept of refiguration of spaces. Finally, in order to better understand the economy, it would be beneficial to explore in greater detail how social institutions and objectified space are entwined. 


\section{Acknowledgements}

The chapter is based on our joint research within the project "Knowledge and Goods: Consumers' and Producers' Spatial Knowledge" (A03), which is part of the Collaborative Research Center "Re-Figuration of Spaces" (CRC 1265) funded by the German Research Foundation (DFG) (project number 290045248).

\section{References}

Achen, M., J. Böhmer, M. Gather, and P. Pez. 2008. Handel und Verkehr, Mobilität und Konsum. Mannheim: Meta GIS.

Agergard, A., P. A. Olsen, and J. Allpass. 1970. "The Interaction between Retailing and the Urban Center Structure." Environment and Planning 2: 55-71.

BA (Bundesagentur für Arbeit). 2020. Statistik 7/2020. Tabellen, Beschäftigte nach Berufen (KldB 2010) (Quartalszahlen, Stichtag 31.12.2019). Nürnberg.

Baur, N. 2005. Verlaufsmusteranalyse. Wiesbaden: VS-Verlag für Sozialwissenschaften.

Baur, N. 2007. "Der perfekte Vater." Freiburger Geschlechterstudien 21: 79-114.

Baur, N. 2008. "Konsequenzen des Verlusts des ganzheitlichen Denkens." In Arbeitsmarkt und Sozialpolitik, edited by O. Struck and H. Seifert, 189-229. Wiesbaden: VS-Verlag.

Baur, N., J. Fülling, L. Hering, and S. Vogl. 2019. "Die Verzahnung von Arbeit und Konsum.” In Transformationen der Arbeitsgesellschaft, edited by S. Ernst and G. Becke, 105-132. Wiesbaden: Springer VS. doi: 10.1007/978-3-658-22712-8_5.

Baur, N., L. Hering, M. Löw, and A. L. Raschke. 2014c. "Tradition, Zukunft und Tempo im Friseursalon.” In Städte unterscheiden lernen, edited by S. Frank, P. Gehring, J. Griem, and M. Haus, 97-124. Frankfurt am Main: Campus.

Baur, N., L. Hering, A. L. Raschke, and C. Thierbach. 2014a. "Theory and Methods." Spatial Analysis. HSR 39 (2): 7-50.

Baur, N., M. Löw, L. Hering, A. L. Raschke, and F. Stoll. 2014b. "Die Rationalität lokaler Wirtschaftspraktiken im Friseurwesen." In Soziologie des Wirtschaftlichen, edited by Dieter Bögenhold, 299-327. Wiesbaden.

Bergmann, W. 1983. "Das Problem der Zeit in der Soziologie.” KZfSS 35 (3): 462-504.

Berking, H., and J. Schwenk. 2011. Hafenstädte. Frankfurt am Main: Campus.

Braudel, Fernand. 1958. "Histoire et sciences sociales: La longue durée." Annales 13 (4): 725-753.

Buchmann, M. 1989. "Soziale Verwaltung von Zeit." SZfS 15 (2): 289-299.

Cromley, E. K. 1999. "Mapping Spatial Data.” In Ethnographer's Toolkit 4, edited by J. J. Schensul and M. D. LeCompte, 51-124. Walnut Creek: AltaMira Press.

Dannenberg, P., M. Franz, and A. Lepper. 2016. “Online einkaufen gehen.” In OnlineHandel im Wandel, edited by M. Franz and I. Gersch, 133-156. Mannheim: MetaGIS.

Dederichs, S., and P. Dannenberg. 2017. "Vom Nischenmarkt in die Expansion.” In Einzelhandel in Deutschland, edited by P. Dannenberg, M. Willkomm, and K. Zehner, 1-8. Mannheim: Meta GIS.

Destatis. 2016. Datenreport 2016. Bonn: Destatis/WZB.

Destatis. 2020. Entwicklung der Bruttoverdienste. Accessed July 14, 2020. www.destatis.de/ $\mathrm{DE} /$ Themen/Arbeit/Verdienste/Verdienste-Verdienstunterschiede/Tabellen/langereihe-frueheres-bundesgebiet-1913.html.

Elias, Norbert. (1969) 2002. Die höfische Gesellschaft. Frankfurt am Main: Suhrkamp. 
Engel, E. 1857. "Die vorherrschenden Gewerbezweige in den Gerichtsämtern mit Beziehung auf die Produktions- und Consumverhältnisse des Königreichs Sachsen.” Zeitschrift des statistischen Bureaus des königl. sächs. Ministeriums des Inneren 3 (8/9): 153-182.

Ermann, U., and R. Pütz. 2020. “Geographien des Konsums.” In Geographische Handelsforschung, edited by C. Neiberger and B. Hahn, 63-74. Berlin: Springer Spektrum.

Fülling, J., and L. Hering. 2020. "Markt-Quartier-Milieu." Arbeitsberichte des Geographischen Instituts der Humboldt-Universität zu Berlin 197. Accessed July 17, 2020. www. geographie.hu-berlin.de/de/institut/publikationsreihen/arbeitsberichte/download/ Arbeitsbericht_197.

Fürstenberg, F. 1982. "Institutionalisierung von Interessenkonflikten.” In Kultur und Institution, edited by H. J. Helle, 175-185. Berlin.

Fürstenberg, F. 1986. "Zeit als Strukturelement soziologischer Analyse." In Zeit als Strukturelement von Lebenswelt und Gesellschaft, edited by F. Fürstenberg and I. Mörth, 23-36. Linz: Trauner.

Grunow, D. 2019. "Comparative Analyses of Housework and Its Relation to Paid Work." KZfSS 71: 247-284. doi: 10.1007/s11577-019-00601-1.

Hassink R., O. Ibert, and M. Sarnow. 2020. "Zum sich wandelnden Verhältnis von Innovation und Raum in subnationalen Innovationssystemen." In Innovationssysteme, edited by B. Blättel-Mink and A. Ebner, 163-185. Wiesbaden: Springer.

HDE (Handelsverband Deutschland). 2019. Online-Monitor 2019. Berlin.

Heidenreich, M. 2003. “Territoriale Ungleichheiten in der erweiterten EU.” KZfSS 55 (1): $1-28$.

Heidenreich, M., and N. Baur. 2015. "Locations of Corporate Headquarters in Europe." In Transnational Corporations and Transnational Governance, edited by S. Lundan, 177-207. Basingstoke: Palgrave.

Hering, H. 2020. "Digitales Gemüse-Wie die Materialität der Waren die Organisation des Online-Handel beeinflusst." 3. Presentation at the Workshop of the "Arbeitskreis Digitalisierung und Organisation," 05./06.03.20.

Hering, L., and N. Baur. 2019. "Die Verschränkung des Lokalen und Globalen an Einkaufsorten.” In Komplexe Dynamiken globaler und lokaler Entwicklungen, edited by N. Burzan. http://publikationen.soziologie.de/index.php/kongressband_2018/article/view/1011.

Hofmeister, H. 2002. Couples' Commutes to Work Considering Workplace, Household, and Neighborhood Contexts. Ann Arbor: UMI.

Hofmeister, H., and P. Moen. 2012. "Commuting.” In Families with Futures 2, edited by M. W. Karraker and J. R. Grochowski, 25-26. New York: Routledge.

Jenne, A. 2017. "Einzelhandelsstandort Flughafen.” In Einzelhandel in Deutschland, edited by P. Dannenberg, M. Willkomm, and K. Zehner, 107-132. Mannheim: Meta GIS.

Jürgens, U. 2013. "Nahversorgung durch Aldi, Lidl und Co." Geographische Rundschau 65 (3): $50-57$.

Korn, J. 2006. "Transiträume als Orte des Konsums." PhD thesis, Humboldt-Universität zu Berlin. doi: 10.18452/15509.

Kulke, E. 2005. "Räumliche Konsumentenverhaltensweisen.” In Dem Konsumenten auf der Spur, edited by E. Kulke, 9-26. Passau: LIS.

Kulke, E. 2017. Wirtschaftsgeographie. Paderborn: Schöningh.

Kulke, E. 2019. “Online-Einzelhandel in Deutschland.” Praxis Geographie 12: 9-13.

Kulke, E. 2020. "Neue Dimensionen des Konsums." Berichte Geographie und Landeskunde 93 (1/2): 5-10.

Kulke, E., and J. Rauh, eds. 2014. Das Shopping Center Phänomen. Mannheim: Meta GIS.

Lange, S. 1973. Wachstumstheorie zentralörtlicher Systeme. Münster. 
Löw, M. 2001. Raumsoziologie. Frankfurt am Main: Suhrkamp.

Luckmann, T. 1986. "Zeit und Identität.” In Zeit als Strukturelement von Lebenswelt und Gesellschaft, edited by F. Fürstenberg and I. Mörth, 135-174. Linz: Trauner.

Martin, N. 2006. Einkaufen in der Stadt der kurzen Wege? Mannheim: Meta GIS.

Massey, D. 2005. For Space. London: Sage.

Maurer, A. 1992. Alles eine Frage der Zeit. Berlin: Sigma.

Neiberger, C., and M. Steinke. 2020. "Dynamik der Betriebsformen.” In Geographische Handelsforschung, edited by C. Neiberger and B. Hahn, 27-38. Berlin: Springer Spektrum.

Nelson, R. L. 1958. The Selection of Retail Location. New York: Dodge.

Papastefanou, G., and D. Zajchowski. 2016. "Time for Shopping." International Journal of Time Use Research 13 (1): 109-131. doi: 10.13085/eIJTUR.13.1.109-131.

Procher, V., and C. Vance. 2013. "Who Does the Shopping?" Ruhr Economic Papers \#393. RWI. doi: $10.4419 / 86788448$.

Promberger, M., J. Rosdücher, H. Seifert, and R. Trinczek. 1997. Weniger Geld, kürzere Arbeitszeit, sichere Jobs? Berlin: Sigma.

Rinderspacher, J. P. 1988. "Der Rhythmus der Stadt.” Difu-Materialien 1/88. Berlin.

Simmel, G. (1901) 1996. Philosophie des Geldes. Frankfurt am Main: Suhrkamp.

Wallerstein, I. 2004. World-Systems Analysis. Durham: Duke University Press.

Weidenhaus, G. 2015. Soziale Raumzeit. Berlin: Suhrkamp.

Weiss, J. 2006. Umweltverhalten beim Lebensmitteleinkauf. Berlin: menschundbuch. 